Int. J. Dev. Biol. 54: 913-918 (2010)

doi: $10.1387 / \mathrm{ijdb} .092893 \mathrm{pr}$

\title{
A Sox5 gene is expressed in the myogenic lineage during trout embryonic development
}

\author{
PIERRE-YVES RESCAN* and CECILE RALLIERE \\ INRA (National Institute for Agricultural Research), Joint Research Unit for Fish Physiology, Biodiversity \\ and the Environment, INRA Scribe, IFR140, Campus de Beaulieu, Rennes, France
}

\begin{abstract}
Sox proteins form a family of transcription factors characterized by the presence of a DNA-binding domain called the high-mobility-group domain (HMG). The presence of a large number of potential Sox5 binding sites in the trout promoter of Pax7, a gene which has emerged as an important regulator of neural and somite development, prompted us to clone trout Sox 5 and to examine its expression pattern in the developing trout embryo. Using whole mount in situ hybridisation, we show here that the Sox 5 transcript is first expressed before segmentation in the whole presomitic mesoderm. In newly formed somites, Sox5 labelling was observed in myogenic progenitor cells of the posterior and anterior walls. As the somite matured rostrocaudally, Sox 5 expression disappeared from the differentiating embryonic myotome, deep in the somite, to become restricted to the undifferentiated myogenic precursors forming the dermomyotome-like epithelium at the surface of the embryonic myotome. Sox 5 was also expressed in the developing nervous system and in pectoral fin buds. On the whole, this work suggests a hitherto unappreciated role for Sox5 in regulating myogenic cells destined to muscle formation and growth.
\end{abstract}

KEY WORDS: Sox5, somite, myotome, external cell layer, dermomyotome, teleost

\section{Intoduction}

Sox proteins are transcription factors which contain a DNAbinding domain called the high-mobility-group domain (HMG). They bind to the minor groove of DNA and recognize the consensus motif $(A / T)(A / T) C A A(A / T)$ (Mertin et al. 1999). Several Sox proteins have been shown to play major role in vertebrate development including early embryogenesis, gastrulation and neural induction, and to contribute to differentiation in many lineages (Guth and Wegner, 2008). Sox proteins are categorized into several subgroups on the basis of sequence similarity within the HMG box and other domains (Schepers et al. 2002).

Myogenic differentiation is controlled by a complex transcriptional regulatory network involving the four myogenic regulatory factors (MRFs) MyoD, myf5, myogenin and MRF4, which direct the transcription of muscle structural genes (Buckingham, 1992). MRFs act downstream of, or in parallel with, the paired domain and homeobox-containing transcription factors Pax3 and Pax7 which are precociously expressed in the dermomyotome, a somite derivative from which arise the myogenic precursors necessary for embryonic myotome development and muscle growth
(Buckingham and Relaix, 2007). An external cell layer of undifferentiated Pax-7 positive myogenic cells surrounds the primary myotome in the fish embryo. This external cell layer, that exhibits many features of the amniote dermomyotome (Devoto et al. 2006), derives from the anterior somitic domain by a cell arrangement and provides myogenic cell precursors necessary for mediolateral expansion of the embryonic myotome (Hollway et al. 2007; Stellabotte et al. 2007; Steinbacher et al. 2008).

As with MRF and Pax7 genes, several Sox genes have been shown to regulate muscle differentiation. Thus Sox8 and Sox15 are expressed in muscle satellite cells and are down- regulated during myogenic differentiation (Schmidt et al. 2003; Beranger et al. 2000). Mice lacking Sox15 are viable but appear to have impaired skeletal muscle regeneration (Lee et al. 2004). On the other hand, Sox6 has been shown to play a critical role in the fiber type differentiation of skeletal muscle both in both the mouse and fish. Indeed, all fetal muscle fibers in Sox6 null mouse embryos

Abbreviations used in this paper: HMG, high mobility group (domain); MRF, myogenic regulatory factor.

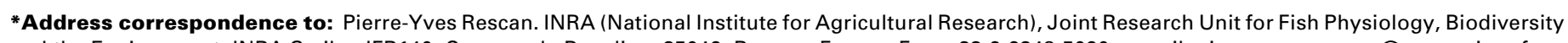

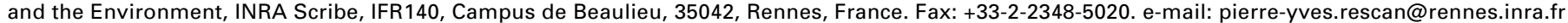

Supplementary Material for this paper (5' flanking sequence of the trout Pax7 gene) is available at: http://dx.doi.org/10.1387/ijdb.092893pr 


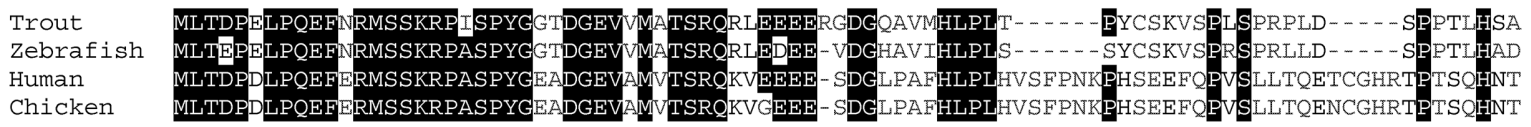

Chicken MLTDPDLPQEFERMSSKRPASPYGEADGEVAMVTSROKVGEEE-SDGLPAFHLPLHVSFPNKPHSEEFOPVSLLTQENCGHRTPTSOHNT
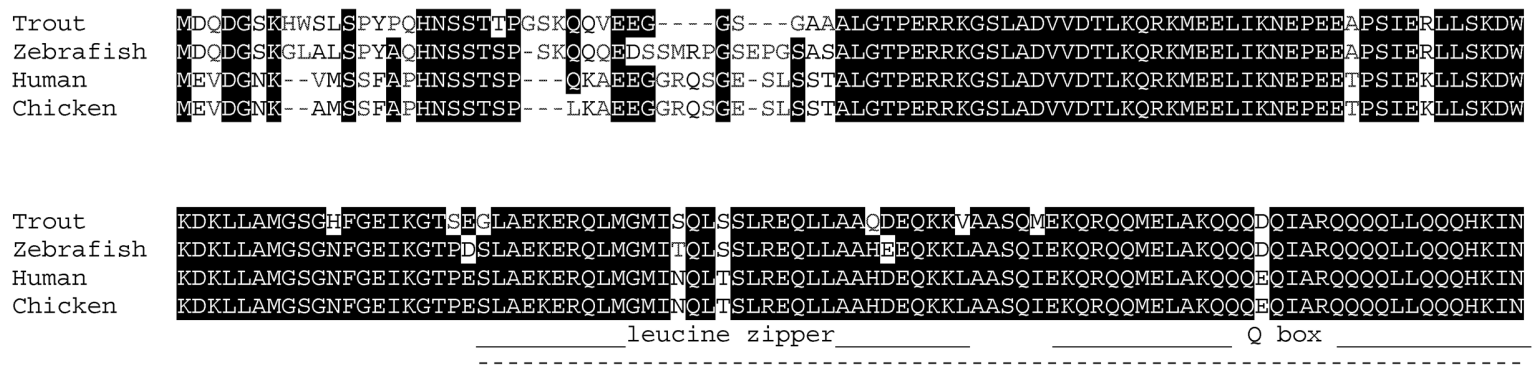

Trout
Zebrafish
Human
Chicken

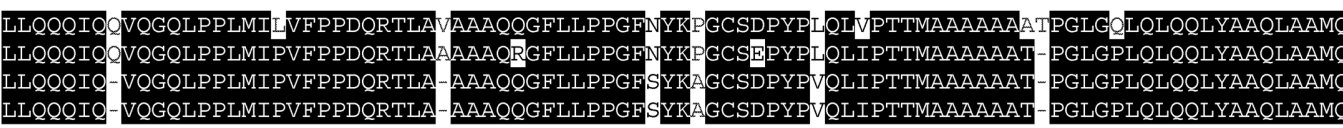

$-\cdots-\cdots-1-\cdots$

Trout

Zebrafish

Human

Chicken
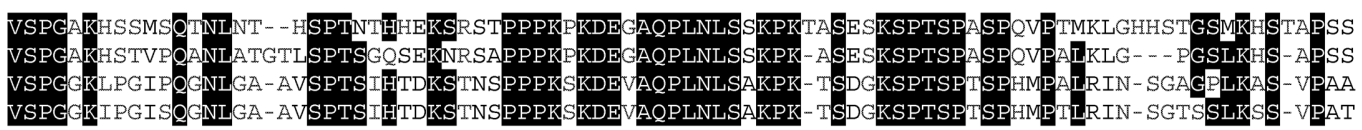

Trout
Zebrafish
Human
Chicken
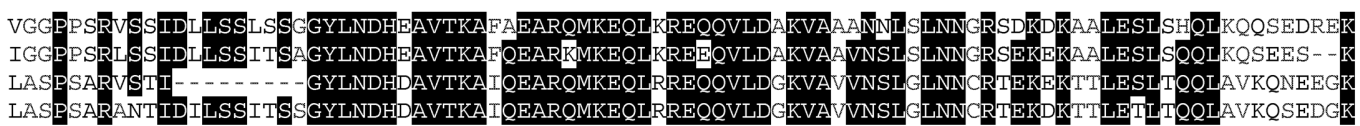

Trout
Zebrafish
Human
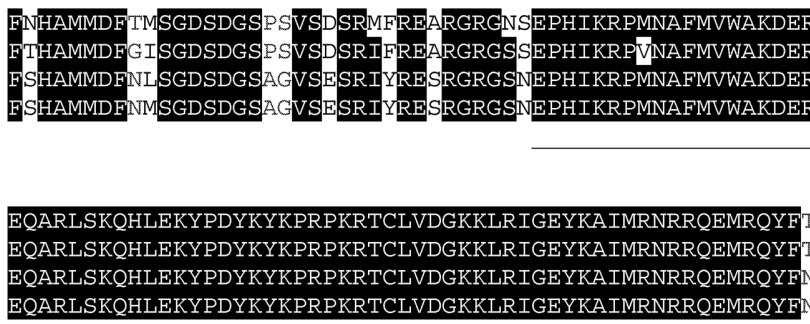

Trout

Zebrafish

Human

Chicken
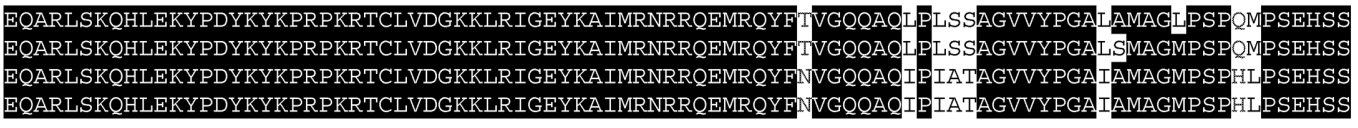

Trout

Zebrafish

Human

Chicken

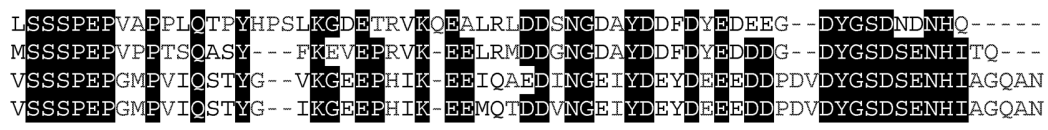

Fig. 1. Sequence comparison of Sox 5 aminoacids between different species. The sequence of the trout Sox 5 gene product (FJ713023) is compared to that of the zebrafish (AY730586), human (NP_008871) and chicken (CAF25288). The shading indicates identity. Conserved regions are shown as lines (Leucine zipper, $Q$ box and HMG box) or dotted lines (two coiled coil regions).

maintain slow fiber characteristics (Hagiwara et al. 2007), while forcing the expression of Sox6 in zebrafish embryo adaxial cells inhibits the expression of Prox1, a gene involved slow fiber maturation (Hofsten et al. 2008).

Sox5 belongs to the SoxD subgroup together with Sox6 and Sox13 and is primarily expressed in cartilage, its expression being associated with the chondrocyte phenotype (Lefebvre et al. 1998). Sox5 transcript has also been found in many adult tissues, including the brain, kidney, lung and skeletal muscle (lkeda et al. 2002). The identification of several potential Sox5-binding sites in the promoter of Pax7, which is a major developmental gene, led us to analyze the expression of Sox 5 in trout embryos, particularly in relation with somite development.

\section{Results and Discussion}

\section{The trout Pax7 proximal promoter contains several Sox5 binding sites}

In an attempt to identify genes precociously expressed in myogenic progenitor cells of the trout embryo we searched for 
potential transcription factor binding motifs present in the trout promoter of $\mathrm{Pax} 7$, a gene that marks myogenic cells (Buckingham and Relaix, 2007). For this purpose, the trout $\mathrm{Pax} 7$ gene was isolated by screening a rainbow trout bacterial artificial chromosome (BAC) library and then sequenced upstream to the initiation codon (GenBank accession no. FJ713022). Computational characterisation of the promoter led to the identification of five TRANSFAC motifs for Sox5 (ATTGTT) (Denny et al. 1992) in position -2665, -2639,-2617, -2018 and 1338 relative to the translation initiation codon (Supp. Fig. S1). We thus considered that Sox5 was a candidate gene to be transcribed in embryonic myogenic precursor cells, so its expression in developing embryo was therefore examined.

\section{Molecular cloning of trout Sox 5 cDNA}

All the PCR products generated in course of this study were overlapping and resulted in a $2289 \mathrm{nt}$ cDNA (GeneBank accession no. FJ713023) with an open reading frame encoding a 762 amino acid protein (Fig. 1). The BlastP best match of this protein was zebrafish Sox5.

The identity of putative trout Sox 5 protein was further confirmed using the Figenix platform which unambiguously clustered it with Sox5 proteins within the SoxD subgroup (fig. 2). Alignment of trout

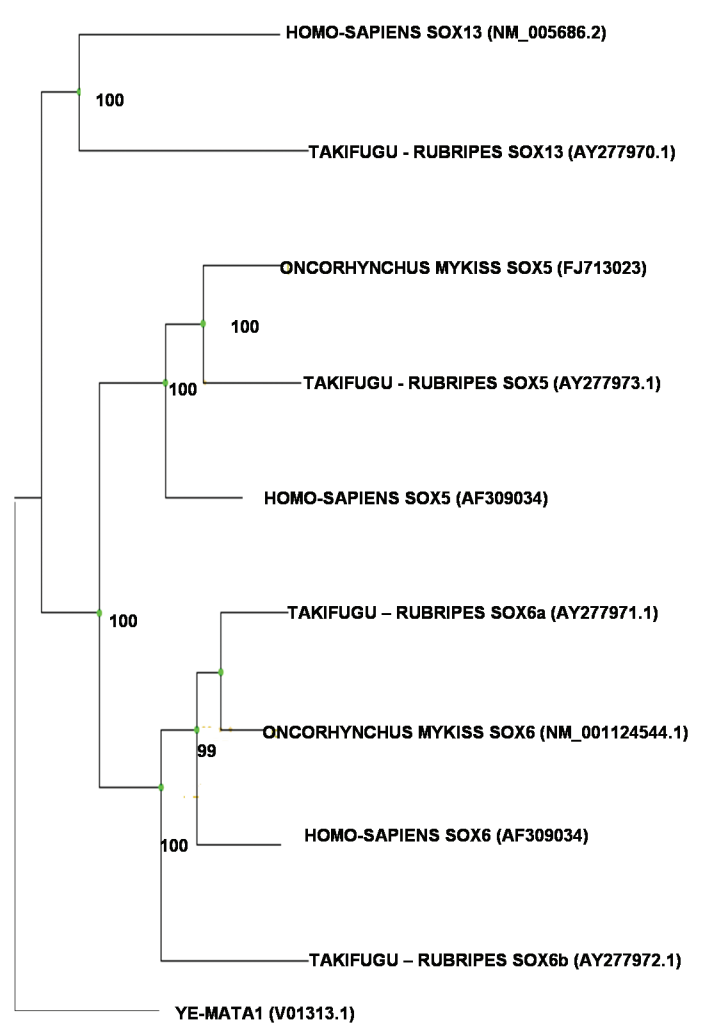

Fig. 2. Phylogeneic tree showing the relationship of the trout Sox5 protein to other Sox proteins belonging to the SoxD subgroup. This tree was constructed using the phylogenomic analysis pipeline available in Figenix automated genomic annotation platform (Gouret et al., 2005); Bootstrap values are given at each branch. Mata-1 was used as an outgroup
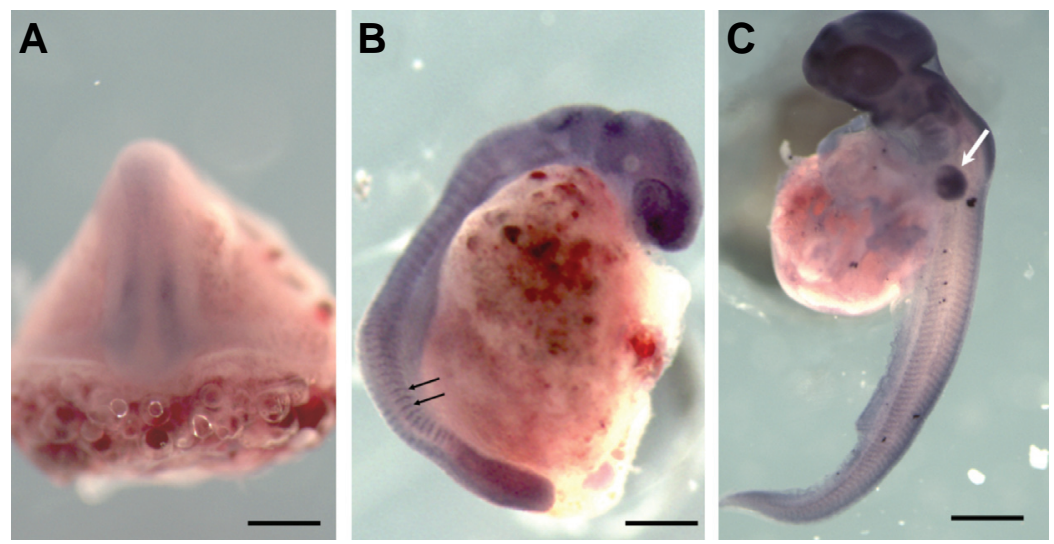

Fig. 3. Expression of Sox5 in the trout embryo. (A) Stage 10A embryo, dorsal view: Sox5 labelling is observed in the paraxial mesoderm on either side of the elongating embryonic shield. (B) Stage 15 embryo (approximately 35 somites), lateral view: Sox5 transcript accumulates in the paraxial mesoderm, somites (arrows) and developing brain. (C) Stage 20 embryo (segmentation is complete to the tip of the tail), lateral view: Sox5 transcript is evidenced in somite, branchial arches and pectoral fins (white arrow). Scale bar, $120 \mu \mathrm{m}$ in (A), $300 \mu \mathrm{m}$ in (B) and $400 \mu \mathrm{m}$ in (D).

Sox5 with other vertebrate Sox5 proteins revealed several common characteristics such as an HMG box, two coiled coil region, a leucine zipper and a $Q$ box (Fig. 1).

\section{Expression pattern of Sox5 in developing trout embryo}

Whole mount in situ hybridisation using an antisense Sox5 digoxigenin-labeled probe showed that Sox5 transcript was first present in two presomitic bands prior to the onset of somitogenesis (stage 10A of Ballard, 1973) (Fig. 3A). At the beginning of the somitogenesis, 6-10 somites formed simultaneously in the rostral paraxial mesoderm (stage 10B). At this stage Sox5 transcript was observed within the elongating presomitic mesoderm and in somites. As somitogenesis proceeded along an anteroposterior axis (stages $10 \mathrm{~B}$ to 19), labelling extended progressively to more caudal somites (Fig. 3 B,C). Transverse sections showed that Sox5 transcript was present throughout the rostral presomitic mesoderm including adaxial and lateral cells (Fig. 5A). In the newly formed somites, Sox 5 labelling appeared to be intense in a central stripe (Fig. 3B). Frontal sections indicated that this aspect resulted from the marked accumulation of Sox 5 transcript in the cytoplasm of myogenic cell precursors of the posterior and anterior walls and its weak accumulation in the large nuclei mostly located at the apical pole of these cells (Fig 4A,B). Shortly after their incorporation into somite, the adaxial cells which had already started to express myogenin (Fig. 4C) ceased to express Sox5 (Fig. 4B). It is now established that adaxial cells, which are the first to differentiate, migrate radially through the somite to form a superficial layer of embryonic slow muscle fibres covering the fast embryonic muscle fibres that originate from the posterior somitic compartment (Devoto et al. 1996; Hollway et al. 2007; Stellabotte et al. 2007). As somite maturation proceeded, Sox5 expression gradually disappeared from the differentiating embryonic myotome, deep in the somite (Fig. 5B), to become restricted to the surrounding external cell layer (Fig. 5 C,D). This external epithelium, produced by the displacement of somitic anterior cells towards the outermost part of the somite (Hollway et al. 2007; Stellabotte et al. 2007), exhibits many features of the amniote 

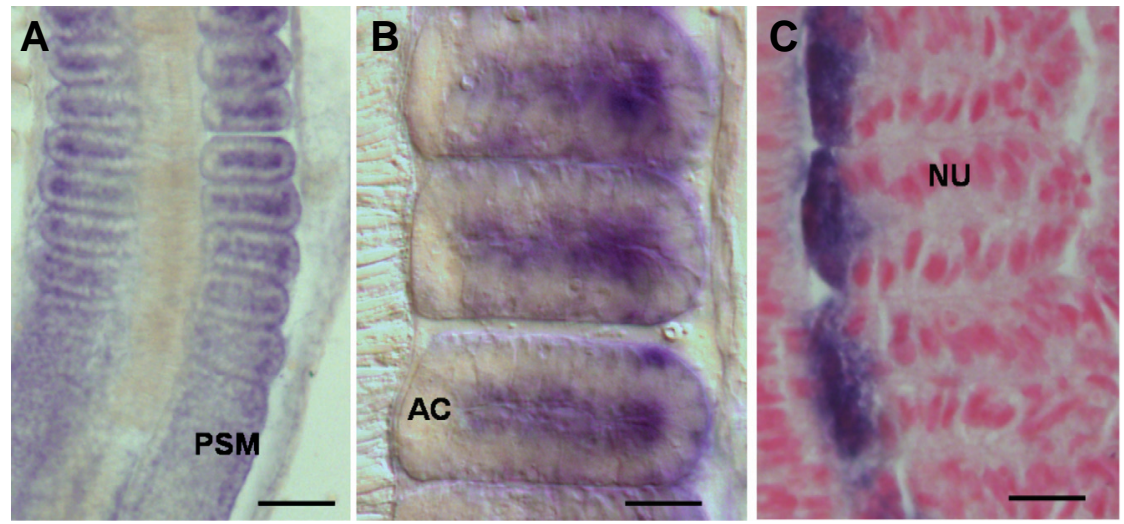

Fig. 4. Expression of Sox 5 and myogenin in newly-formed trout somites. (A-C) Stage 15 embryo, frontal sections. (A) Sox5 labelling is intense in a stripe in the middle of the neoformed somites. (B) Higher magnification of (A), Sox 5 transcript strongly accumulates in the cytoplasm of the somitic cells in the posterior and anterior walls, but is hardly detected in nuclei. (C) Myogenin is expressed in adaxial cells, nuclei are large and nearly fill the apical domain of the somitic cells. Scale bar, $50 \mu \mathrm{m}$ in (A) and $15 \mu \mathrm{m}$ in (B,C). psm, presomitic mesoderm, nu, nucleus; ac, adaxial cell.

dermomyotome, including the expression of equivalent gene orthologs (Devoto et al. 2006; Dumont et al. 2008) and the ability to provide myogenic cells for myotome expansion (Hollway et al. 2007; Stellabotte et al. 2007; Steinbacher et al. 2008). That Sox 5 expression faded in differentiating cells of the primary myotome while being maintained in somitic external cells

A

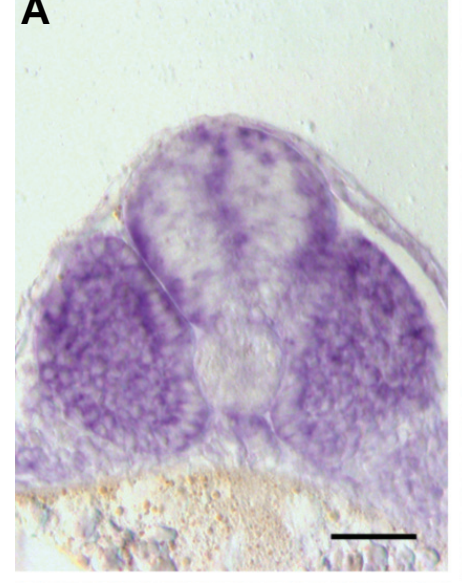

C

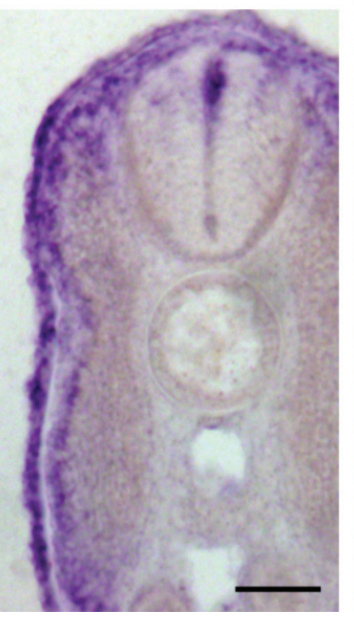

B

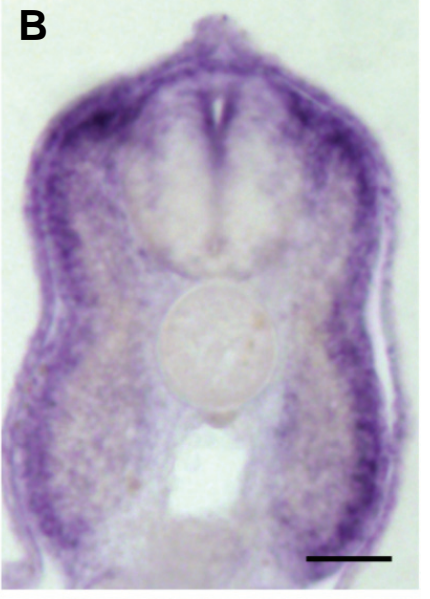

D

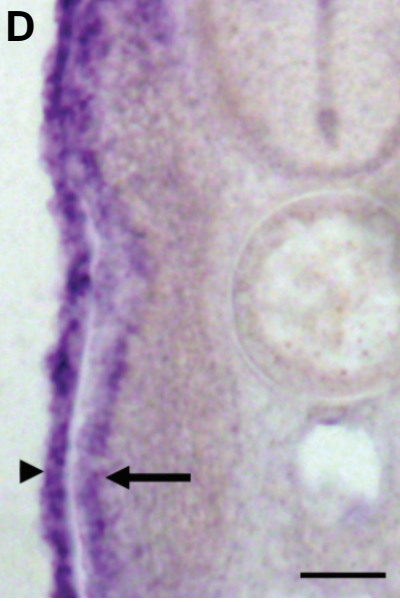
sclerotome cells surrounding the notochord and neural tube (Smits and Lefebvre, 2003). The Sox5 gene identified in this study was not expressed in notochord and sclerotome cells of the trout embryo (Fig. 5 B,C,D). Given the ancient wholegenome duplication that occurred in the teleost fish lineage, after split of lobe and ray finned lineages (Jaillon et al. 2004), we can not exclude that an additional Sox 5 gene copy with an expression in the forming vertebral column exists in the trout genome. Alternatively, the acquisition of a chondrogenic function by Sox 5 may be specific to mammal evolution.

In conclusion, and on the basis of the presence of multiple potential Sox5 binding sites on the promoter of the Pax7 developmental gene, we examined the expression pattern of Sox5 in developing trout embryos. The expression data showed that Sox5 was transcribed in somite myogenic precursors giving rise to the embryonic myotome and in those forming the dermomyotome-like epithelium at the surface of the embryonic myotome. This work thus suggests a hitherto unappreciated role for Sox 5 in regulating myogenic progenitor cells destined to muscle formation and growth.

\section{Materials and Methods}

\section{Fish maintenance}

All experiments were carried out on the rainbow trout Oncorhynchus mykiss (Walbaum). Eggs were collected at the experimental facilities of the INRA Drennec fish farm (Finistère, France). After artificial insemination, the eggs were incubated at $10^{\circ} \mathrm{C}$ in recirculating dechlorinated water. Chemical water parameters were regularly monitored. Oxygen levels were always above $98 \%$ saturation.

Fig. 5. Sox5 somitic expression gradually becomes restricted to external cells. (A) Stage 25 somite embryo, transverse section through the anterior presomitic mesoderm. (B) Stage 55-somite embryo, transverse section through posterior trunk. (C) Eyed-stage trout embryo, transverse section through posterior trunk. (D) Higher magnification of (C); Sox5 transcript is restrictedly present in the external cell layer situated at the outermost domain of the somite (arrow) just beneath the epidermis (arrowhead). Scale bars: $50 \mu \mathrm{m}$ in (A, B,C) and $30 \mu \mathrm{m}$ in (D). 


\section{BAC library screening and sequencing of the 5'-flanking regulatory region of Pax7}

To isolate the trout $\mathrm{Pax} 7$ promoter, a 5.3X genome coverage rainbow trout bacterial artificial chromosome (BAC) library (Palti et al. 2004) was screened by PCR using primers designed from the salmon Pax7 cDNA sequence (Gottenspare et al. 2006). DNA from positive BACs was isolated using the Nucleobond BAC Maxi kit (BD Bioscience). The primer walking method was then used to obtain a genomic sequence directly from the selected BACs. The samples were sequenced using an automatic sequencing system (ABI Prism 310, PE Biosystems). Sequence analysis of the 5'regulatory region was performed with the on-line program TRES (transcription regulatory element search: http://bioportal.bic. nus.edu.sg/tres/) using transfac weight matrices (Wingender et al. 2000) with a stringent matrix cut-off score $>99$.

\section{Isolation of trout Sox5 cDNA}

Two rainbow trout ESTs (CX252793 and CX 252794) were selected after a tblastn search using the zebrafish (CAK04950) Sox5 sequence. The sequencing of the corresponding clone and blastx analysis led to the identification of a cDNA fragment (position 1135-2082 in the full length sequence (GeneBank accession no. FJ713023)) encoding a partial protein sequence highly related to Sox5. The missing 5'part of the cDNA was amplified from a rainbow trout embryonic cDNA libraries (Uni-ZAP Custom cDNA Library; Stratagene, La Jolla, CA) using the reverse primer ATGACAGCA- GGTCTATGGAGCTGAC (position: 13361312) and the forward primer AGTTCCCACAGACCTATTCCAGC that flanks in 5' the presumptive open reading frame of salmon Sox5 cDNA (EST: GE773617). The missing 3' part of the cDNA was amplified using the forward primer GCCCAGCTGCCCTTGTCCTCGGCG (position 2005-2028) and the reverse primer 5'TTCTGATTGGCTCTGCTTCCAGA that flanks in 3' the sequence of the presumptive open reading frame of salmon Sox 5 cDNA (DY693671). Additional PCR fragments were then produced (positions-398-1234 and 1312-2028) to confirm the overlapping of the 5'and 3' ends with the initial truncated trout Sox 5 cDNA. Purified PCR products were cloned onto the pGEM-T vector (Promega) and sequenced using an automatic sequencing system (ABI Prism 310, PE Biosystems). Multiple amino acid sequence alignments were constructed using Clustal W software. The phylogenetic analysis was performed using the phylogenomic analysis pipeline available in the FIGENIX platform (http://www.up.univmrs.fr/evol/figenix/) (Gouret et al. 2005). For this purpose Sox proteins of the group D, to which Sox5 belongs (Koopman et al., 2004), were entered.

\section{Whole-mount in situ hybridisation}

Embryos were dechorionated with fine forceps and fixed overnight at $4^{\circ} \mathrm{C}$ in paraformaldehyde in phosphate buffered saline (PBS). The specimens were then dehydrated and stored in methanol at $-20^{\circ} \mathrm{C}$. After rehydration in graded methanol-PBS baths, the embryos were processed according to established automated procedures. Hybridizations were performed with Sox5 and myogenin digoxigenin-11UTP* labelled antisense riboprobes. Myogenin riboprobe was complementary of the 3'untranslated region and the 3' two thirds of the coding sequence of the trout myogenin transcript (Rescan et al. 1995). Sox5 antisense RNA probes was synthesised from a PCR-amplified template that included the HMG domain (position 1136- 2082 in the full length sequence). This Sox 5 riboprobe did not cross-hybridize with its closest paralog Sox6 as shown by the distinct expression pattern of Sox6 (data not shown).

\section{Histological methods}

For histological examinations, embryos were embedded in $30 \%$ ovalbumin, $0.5 \%$ gelatine and $1 \%$ gluteraldehyde in PBS. Blocks were sectioned at $30 \mu \mathrm{m}$ on a Leica vibratome. The resulting sections were mounted in Mowiol

\section{Acknowledgements}

This work was supported by grants from INRA (Institut National de la Recherche Agronomique). We would like to thank $Y$. Palti and C. E. Rexroad III for sharing the rainbow trout BAC library, $C$. Sevellec for preparing histological sections, K.C Tabet for screening the BAC library, Cecile Melin for obtaining and rearing trout embryos and Thomas Desvigne for the use of the FIGENIX platform.

\section{References}

BALLARD, W. W. (1973). Normal embryonic stages for salmonid fishes, based on Salmo gairdneri Richardson and Salvelinus fontinalis (Mitchill). J Exp Zoo/184: 7-26.

BÉRANGER, F., MÉJEAN, C., MONIOT, B., BERTA, P., and VANDROMME, M. (2000). Muscle differentiation is antagonized by SOX15, a new member of the SOX protein family. J Biol Chem 275:16103-16109.

BUCKINGHAM M. (1992). Making muscle in mammals. Trends Genet4: 144-148.

BUCKINGHAM, M. and RELAIX, F. (2007). The role of pax genes in the development of tissues and organs: pax3 and pax7 regulate muscle progenitor cell functions. Annu Rev Cell Dev Bio/23: 645-673.

DENNY, P., SWIFT, S., CONNOR, F., and ASHWORTH, A. (1992). An SRY-related gene expressed during spermatogenesis in the mouse encodes a sequencespecific DNA-binding protein. EMBO J. 11: 3705-3712.

DEVOTO, S. H., MELANCON, E., EISEN, J. S. and WESTERFIELD, M. (1996). Identification of separate slow and fast muscle precursor cells in vivo, prior to somite formation. Development 122: 3371-3380.

DEVOTO, SH., STOIBER, W., HAMMOND, C. L., STEINBACHER, P., HASLETT, J. R., BARRESI, M. J., PATTERSON, S. E., ADIARTE, E. G. and HUGHES, S. M. (2006). Generality of vertebrate developmental patterns: evidence for a dermomyotome in fish. Evol Dev 8: 101-110.

DUMONT, E., RALLIERE, C. and RESCAN, P. Y. (2008). Identification of novel genes including Dermo-1, a marker of dermal differentiation, expressed in trout somitic external cells. J Exp Bio/211:1163-1168.

GOTTENSPARRE, S. M., ANDERSSON, E., WARGELIUS, A., HANSEN, T. and JOHNSTON I. A. (2006). Insight into the complex genetic network of tetraploid Atlantic salmon (Salmo salar L.): Description of multiple novel Pax-7 splice variants. Gene 373: 8-15.

GOURET, P., VITIELLO, V., BALANDRAUD, N., GILLES, A., PONTAROTTIP. and DANCHIN, E. G. (2005). FIGENIX: intelligent automation of genomic annotation: expertise integration in a new software platform. BMC Bioinformatics 6:198.

GUTH, S. I. and WEGNER, M. (2008). Having it both ways: Sox protein function between conservation and innovation. Cell Mol Life Sci65: 3000-3018.

HAGIWARA, N., YEH, M. AND LIU, A. (2007). Sox6 is required for normal fiber type differentiation of fetal skeletal muscle in mice. Dev Dyn 236: 2062-2076.

VON HOFSTEN, J., ELWORTHY, S., GILCHRIST, M.J., SMITH, J. C., WARDLE, F. C. and INGHAM, P. W. (2008). Prdm1- and Sox6-mediated transcriptional repression specifies muscle fibre type in the zebrafish embryo. EMBO Rep 9: 683-689.

HOLLWAY, G. E., BRYSON-RICHARDSON, R., BERGER, S., COLE, N.J., HALL, T. E. and CURRIE, P. D. (2007). Whole somite rotation generates muscle progenitor cell compartments in the developing embryo. Dev Cel/12: 207-219.

IKEDA, T., ZHANG, J., CHANO, T., MABUCHI, A., FUKUDA, A., KAWAGUCHI, H., NAKAMURA, K. and IKEGAWA, S. (2002). Identification and characterization of the human long form of Sox5 (L-SOX5) gene. Gene 298:59-68.

JAILLON, O., AURY, J. M., BRUNET, F., PETIT, J. L., STANGE-THOMANN, N., MAUCELI, E., BOUNEAU, L., FISCHER, C., OZOUF-COSTAZ, C., BERNOT, A., et al. (2004). Genome duplication in the teleost fish Tetraodon nigroviridis reveals the early vertebrate proto-karyotype. Nature. 431: 946-957

KOOPMAN, P., SCHEPERS, G., BRENNER, S. and VENKATESH, B. (2004). Origin and diversity of the SOX transcription factor gene family: genome-wide analysis in Fugu rubripes. Gene 328:177-86

LEE, H. J., GÖRING, W., OCHS, M., MÜHLFELD, C., STEDING, G., PAPROTTA, I., ENGEL, W. and ADHAM, I. M. (2004). Sox15 is required for skeletal muscle regeneration. Mol Cel/ Bio/24: 8428-8436. 
LEFEBVRE, V., LI, P. and DE CROMBRUGGHE, B. (1998). A new long form of Sox5 (L-Sox5), Sox6 and Sox9 are coexpressed in chondrogenesis and cooperatively activate the type II collagen gene. EMBO J17: 5718-5733.

MACQUEEN, D. J. and JOHNSTON, I. A. (2008). Evolution of follistatin in teleosts revealed through phylogenetic, genomic and expression analyses. Dev Genes Evol218: 1-14

MERTIN, S., MCDOWALL, S. G. and HARLEY, V. R. (1999). The DNA-binding specificity of SOX9 and other SOX proteins. Nucleic Acids Res 27: 1359-1564.

PALTI, Y., GAHR, S. A., HANSEN, J. D. and REXROAD C. E. (2004). Characterization of a new BAC library for rainbow trout: evidence for multi-locus duplication. Anim Genet 35: 130-133.

RESCAN, P. Y., GAUVRY, L. and PABOEUF, G. (1995). A gene with homology to myogenin is expressed in developing myotomal musculature of the rainbow trout and in vitroduring the conversion of myosatellite cells to myotubes. FEBS Lett 362: 89-92.

SCHEPERS, G. E., TEASDALE, R. D. and KOOPMAN, P. (2002). Twenty pairs of Sox: extent, homology, and nomenclature of the mouse and human sox transcription factor gene families. Dev Ce//3: 167-170.

SCHMIDT, K., GLASER, G., WERNIG, A., WEGNER, M. and ROSORIUS, O. (2003). Sox8 is a specific marker for muscle satellite cells and inhibits myogenesis. $\checkmark$ Biol Chem 278: 29769-29775.

SMITS, P. and LEFEBVRE, V. (2003). Sox5 and Sox6 are required for notochord extracellular matrix sheath formation, notochord cell survival and development of the nucleus pulposus of intervertebral discs. Development 130:1135-1148.

STEINBACHER, P., STADLMAYR, V., MARSCHALLINGER, J., SÄNGER, A. M and STOIBER, W. (2008). Lateral fast muscle fibers originate from the posterior lip of the teleost dermomyotome. Dev Dyn 237: 3233-3239.

STELLABOTTE, F., DOBBS-MCAULIFFE, B., FERNANDEZ, D. A., FENG, X. and DEVOTO, S.H. (2007). Dynamic somite cell rearrangements lead to distinct waves of myotome growth. Development 134: 1253-1257.

WINGENDER, E., CHEN, X., HEHL, R., KARAS, H., LIEBICH, I., MATYS, V., MEINHARDT, T., PRÜSS, M., REUTER, I. and SCHACHERER, F. (2000). TRANSFAC: an integrated system for gene expression regulation. Nucleic Acids Res 28: 316-319.

\section{Further Related Reading, published previously in the Int. J. Dev. Biol.}

See Special Issue Pattern Formation edited by Michael K. Richardson and Cheng-Ming Chuong at: http://www.ijdb.ehu.es/web/contents.php?vol=53\&issue =5-6

S. macrurus myogenic regulatory factors (MRFs) induce mammalian skeletal muscle differentiation; evidence for functional conservation of MRFs

Hyun-Jung Kim, Robert Güth, Colleen B. Jonsson and Graciela A. Unguez

Int. J. Dev. Biol. (2009) 53: 993-1002

Cloning and developmental expression of the soxB2 genes, sox14 and sox21, during Xenopus laevis embryogenesis

Doreen D. Cunningham, Zhuo Meng, Bernd Fritzsch and Elena Silva Casey

Int. J. Dev. Biol. (2008) 52: 999-1004

Comparative expression analysis of $\mathrm{Pax} 3$ and $\mathrm{Pax} 7$ during mouse myogenesis

David Horst, Svetlana Ustanina, Consolato Sergi, Gregor Mikuz, Herbert Juergens, Thomas Braun and Eugene Vorobyov

Int. J. Dev. Biol. (2006) 50: 47-54

Myogenic potential of mouse primordial germ cells

Francesca-Gioia Klinger, Maria-Lucia Scaldaferri, Anna Di Carlo, Marta Baiocchi, Marcello Coletta, Giulio Cossu and Massimo De Felici

Int. J. Dev. Biol. (2003) 47: 303-305

Myogenesis in cultures of uniparental mouse embryonic stem cells: differing patterns of expression of myogenic regulatory factors

L A McKarney, M L Overall and M Dziadek

Int. J. Dev. Biol. (1997) 41: 485-490

5 yr ISI Impact Factor $(2008)=3.271$

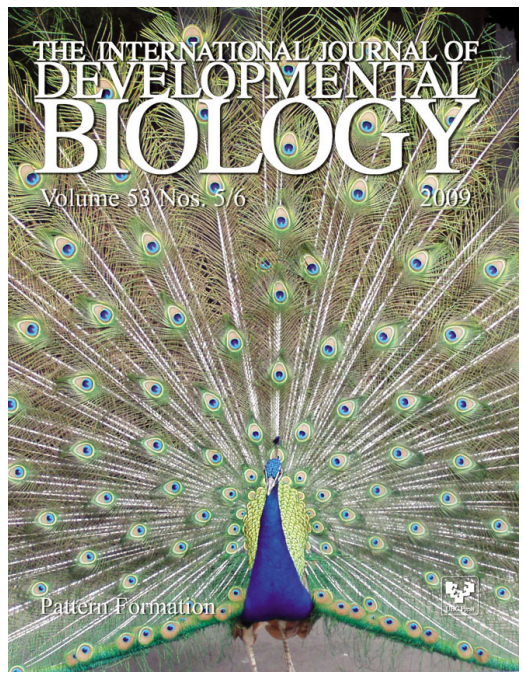

